\title{
IMPROVEMENT OF GROWTH PARAMETERS OF PRUNE CALLUS CULTURES DESTINED TO INITIATE CELL SUSPENSIONS
}

\author{
EWA HANUS-FAJERSKA \\ Botany Department, Horticulture Faculty, Agricultural University \\ Al. 29 Listopada 54, 31-425 Kraków, Poland \\ e-mail: ehanus@ogr.ar.krakow.pl
}

(Received: June 17, 2005. Accepted: December 28, 2005)

\begin{abstract}
Callus was inducted on wounded leaf explants from shoot tips of a particular Prunus domestica 'Węgierka Zwykła' clone cultivated in vitro. The improvement of Sweet Common Prune stock callus tissue parameters has been approached by experiments on culture protocols. Either for the induction or maintenance of tissue modified Murashige and Skoog medium, supplemented with different auxins and cytokinins at varying concentrations, was used. The goal was to obtain the highiest possible proliferative capacity of friable tissue without any signs of cell redifferentiation for about 10 weeks. The choice of auxin was an important factor regulating the rate and kind of tissue growth, and for the examined prune clone auxin alone brought a relatively small proportion of cells into division, so advantageous was to combine it with oxygenated cytokinin. Friable tissue was obtained on media supplemented with dicamba or with picloram, but not with 2.4-D neither alone nor combinated with IBA.
\end{abstract}

KEY WORDS: Prunus domestica, callus culture, growth regulators, friable tissue, proliferation.

\section{INTRODUCTION}

Plant biotechnology continously offers opportunities to increase sustainability and profitability in horticulture. Callus cultures maintained on solid or semisolid media and suspension cell cultures are among the most exploited components of biotechnology techniques. Both types of cultures represent a particulary interesting tool for cell differentiation along with histogenesis researches and for studies on organogenesis. They are commonly used to select mutants, eventually variants with improved stress tolerance for purpose of utilizing regenerated plants in breeding projects. These techniques can also be applied to study stress physiology and genetics at the cellular level. Another frequently used application is subculture of callus lines of several species as material for synhesis of valuable compounds (Malepszy 2001; Stec 1994; Sasaki 2004). Tissue culture methods of Prunus domestica L. have been especially employed to micropropagate precious clones and to increase the efficiency of treatments for variation induction (Jones 1991; Nowak et al. 2004; Predieri 2001). When experi-

\section{Abbreviations:}

BA - benzylaminopurine; 2.4-D - dichlorophenoxyacetic acid; IBA indolebutyric acid; MS - Murashige and Skoog medium; PGR - plant growth regulators; CIM - callus induction medium; CMM - callus maintenance medium; FT - friable tissue ments are to be switched from the level of tissues to the level of isolated cells, an important preliminary step is the assesment of appropriate mass of friable tissue (Chen and Jonard 1994).

Plum pox virus (PPV), common in many Prunus species, is one of the most devastating and rapidly spreading viral pathogen of stone fruit crops. Despite great efforts within Prunus domestica no genotypes resistant to PPV have been found. In susceptible plum cultivars PPV infection can cause an almost complete yield loss, so there is great demand for disease-resistant material for breeding programmes (Navratil et al. 2005; Hartmann 1998). The presented paper has been prepared for the purpose of making a contribution to optimalisation of methods for callus culture in order to improve parameters of Sweet Common Prune clone M-VI-1 cultures used in our laboratory (Hanus-Fajerska and Nowak 2001), promising in the purpose to generate resistance trait. Attention was focused at effects of various PGR concentrations and combinations on callus proliferation and subsequent progressive changes of cultured tissue. The experiment was undertaken to qualify, whether prune callus-cell populations of that particular clone have an absolute requirement for exogenous cytokinin for proper growth. We tried to correlate the high rate of growth with low compactness and maintain the proliferating tissue mass in invariable state. A further aim of presented study was to assess the influence of IBA, 2.4-D, dicamba, piclo- 
ram, and benzylaminopurine (BA) on callus initiated from shoot stockcultures derived from the same Sweet Common Prune plant.

\section{MATERIALS AND METHODS}

\section{Plant material and callus initiation conditions}

This study was performed on micropropagated Sweet Common Prune clone M-VI-1 maintained as shoot culture. The first four expanded leaves were excised from proliferating shoots, and a lamina $0.5-0.8 \mathrm{~cm}$ in length was placed on the contact with callus induction medium (CIM) with the abaxial surface. CIM consisted of modified MS salts and vitamins (Nowak and Miczyński, 1996) supplemented with 3\% (w/v) sucrose, $10 \%(\mathrm{w} / \mathrm{v})$ agar Difco and various PGR as indicated in Table 1. Medium was adjusted to $\mathrm{pH}$ 5.5 before autoclaving. Erlenmayer flasks containing $25 \mathrm{ml}$ of culture medium with 10 explants were incubated in darkness at $24^{\circ} \mathrm{C}$. On $21^{\text {st }}$ day thewhole callus tissue developed on explant was transferred to callus maintenance medium (CMM).

\section{Callus maintenance}

Callus separated from the explants was maintained on callus maintenance medium (CMM); it was still MS modified according Nowak and Miczyński (1996) supplemented with $3 \%(\mathrm{w} / \mathrm{v})$ sucrose, $10 \%(\mathrm{w} / \mathrm{v})$ agar and various PGR as indicated in Table 2. The first transfer on CMM took place three weeks from initiation of callus culture. In each treatment four biweekly done succesive subcultures on CMM were performed.

\section{Statistics}

Two experimental blocks were planned and performed. In experimental block No. I the effect of auxin alone (Experimental treatment 1: picloram), or combination of auxins (Experimental treatment 2: 2.4-D, IBA, picloram) on callus induction, growth and possible signes of differentiation were checked, whereas in experimental block No. II auxin was combinated with cytokinin. These media treatments were as follows: in treatment 3: 2.4-D and BA; in treatment 4: dicamba and BA. The experiments were carried out with at least 50 explants in each treatment. Experiment was repeated twice. Cultures were evaluated every week. Experimental data were: callus fresh weight, callus morphology and histological examination of tissue samples. Data convenient for statistical mean comparisons between all levels of auxins added to the media and auxins with cytokinins respectivelly, were made according Compton (1994) with the Student test (5\% level).

\section{RESULTS}

Leaf explants reacted by callus formation, and response to the callus induction medium largely depended on the PGR regime used, generally speaking auxin alone gave rather poor dedifferentiative effect on explanted lamina tissues in comparison with the case of combinig auxin with cytokinin in the induction medium. A combination of auxin with cytokinin gave a more pronounced response, notably when 2.4-D with BA in 20:1 ratio or dicamba with BA in $10: 1$ ratio were used, as $67 \%$ and $72 \%$ respectively of explants formed visible callus mass within about a week, while on other media callusing was observed between 14-17 days under similar conditions, even if anatomical studies showed that in every evaluated sample cell divisions were initiated during the first week of culture.

As far as phenotypic differences are concerned, clone MVI-1 responded to picloram and dicamba in friable callus formation, but picloram soon gave effect of browning of tissues and differentiation of several cells into tracheary elements (Fig. 1). The series with dicamba combined with BA in ratios: $7: 1$ or $6.6: 1$ used in maintenance medium (CMM) were satisfactory either in aspect of tissue texture

TABLE 1. PGR regime used in Prunus domestica 'Węgierka Zwykła' callus induction medium - CIM.

\begin{tabular}{|c|c|c|c|c|c|}
\hline Auxin & Dose $(\mathrm{mg} / \mathrm{l})$ & Cytokinin & Dose $(\mathrm{mg} / \mathrm{l})$ & A/C ratio* & Remarks \\
\hline Picloram & 0.5 & - & - & - & MS basal medium \\
\hline Picloram & 0.2 & - & - & - & MS modified \\
\hline 2.4-D/IBA & $1.1 / 0.1$ & - & - & - & MS modified \\
\hline 2.4-D & 2.0 & BA & 0.1 & $20: 1$ & MS modified \\
\hline Dicamba & 2.21 & $\mathrm{BA}$ & 0.2 & $10: 1$ & MS modified \\
\hline Dicamba & 1.66 & $\mathrm{BA}$ & 0.2 & $7: 1$ & MS modified \\
\hline
\end{tabular}

* auxin/cytokinin ratio

TABLE 2. PGR regime used in $P$. domestica 'Węgierka Zwykła' callus maintenance medium - CMM.

\begin{tabular}{lcccc}
\hline Auxin & Dose (mg/l) & Cytokinin & Dose (mg/l) & A/C ratio* \\
\hline Picloram & 0.3 & - & - & - \\
Picloram & 0.3 & - & - & - \\
Picloram & 0.2 & - & - & - \\
2.4-D/IBA & $1.1 / 0.1$ & - & 0.1 & - \\
2.4-D & 1.0 & BA basal medium & MS modified & MS modified \\
Dicamba & 0.7 & BA & 0.1 & MS modified \\
Dicamba & 1.5 & BA & 0.2 & MS modified \\
\hline
\end{tabular}

* auxin/cytokinin ratio 

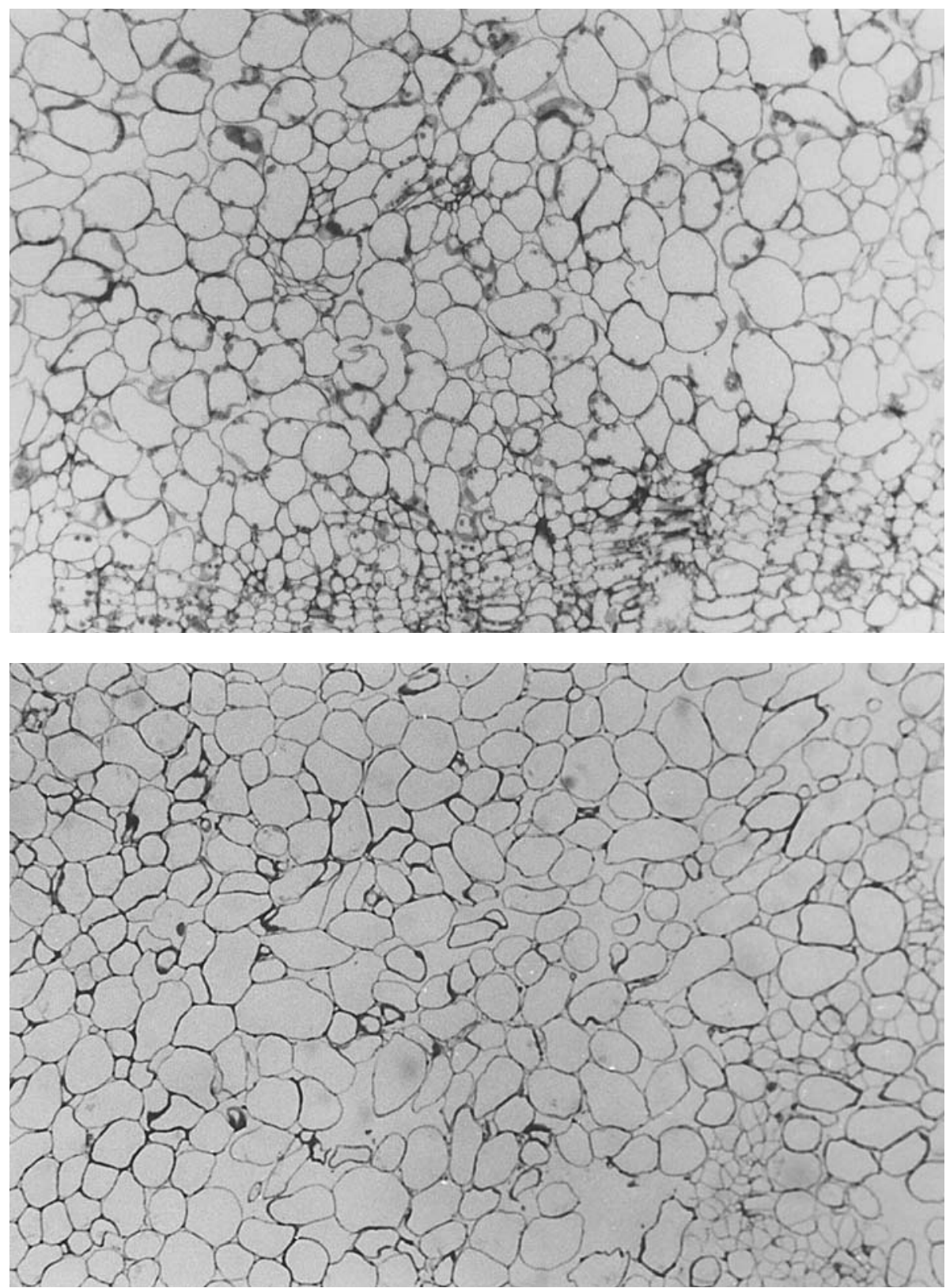

Fig. 1. Representative transverse section of Prunus domestica 'Węgierka Zwykła' M-VI-1 callus tissue during first passage on MS basal maintenance medium with addition of $0.3 \mathrm{mg} / \mathrm{l}$ picloram, where formation of vascular elements can be observed (magn. 144x).
Fig. 2. Histological aspect of friable callus grown on modified MS medium supplemented with $1.5 \mathrm{mg} / \mathrm{l}$ of dicamba and $0.25 \mathrm{mg} / \mathrm{l}$ BA (magn. 144×). or in preserving of examined cell populations in undifferented state. All these cultures remained yellowish and friable (Fig. 2). Significant differences were ascertained in proliferation rate of callus tissue in the second and third passages. The coeficient of increase of callus fresh weight in the second passage was about, and usually more than two, with significant differences between treatments (Table 3 ). The rate of proliferation of tissue diminished with the time. The compact, nodular callus initiated on modified MS medium supplemented with addition of $2.0 \mathrm{mg} / 1$ 2.4-D, $1 \mathrm{mg} / \mathrm{l} \mathrm{BA}$ and maintained on the same medium with plant growth regulator dose reduced to $1.0 \mathrm{mg} / \mathrm{l} 2.4-\mathrm{D}, 0.1$ $\mathrm{mg} / \mathrm{l} \mathrm{BA}$ retained high proliferation rate for 4 subcultures performed.

Under conditions mentioned above two morphologically distinct types of callus tissue become evident. Their occurence was dependent upon the PGR regime used. When sustained proliferation of friable tissue consisting of parenchyma-like cells along with maintenance of proliferating cells in undifferented state for a particular period of time is intended, the combination of dicamba $(1.5 \mathrm{mg} / \mathrm{l})$ with BA $(0.2 \mathrm{mg} / \mathrm{l})$, that is in ratio $6.6: 1$, eventually $7: 1(0.7 \mathrm{mg} / \mathrm{l} \mathrm{di}-$ camba; $0.1 \mathrm{mg} / \mathrm{l} \mathrm{BA}$ ) seem to be the best combinations, but when a compact nodular, highly proliferative tissue is to be obtained, 2.4-D is the most effective auxin, and it also should be combined with BA (Fig. 3).

\section{DISCUSSION}

The developmental drift of living plant cells is relative, and the course of redifferentiation depends both on experimental treetment and on properties of the explanted tissue. In order to induce callus development, explants of most plant species are usually, though not always, cultured on a nutrient medium containing growth-regulating substances (Nowak and Miczyński 2002; Matsua and Yamaki 1988; Pérez-Francés et al. 1995). Although over the past decades the progress in the improvement of tissue-culture procedures has been remarkable, for a particular clone or genotype, 
TABLE 3. Growth patterns of callus tissue initiated from Sweet Common Prune M-VI-1 leaf explants during cultivation on modified MS with different plant growth regulators treetments.

\begin{tabular}{|c|c|c|c|c|c|c|}
\hline $\begin{array}{l}\text { Experimental } \\
\text { treatment }\end{array}$ & $\begin{array}{l}\text { CIM } \\
\text { CMM }\end{array}$ & $\mathrm{A} / \mathrm{C}$ ratio & $\begin{array}{l}\mathrm{A} / \mathrm{C} \text { dose } \\
(\mathrm{mg} / \mathrm{l})\end{array}$ & $\begin{array}{l}\text { Fresh weight } \\
\text { coeficient (35 days) }\end{array}$ & $\begin{array}{l}\text { Fresh weight } \\
\text { coeficient (49 days) }\end{array}$ & $\begin{array}{l}\text { Observations } \\
\text { Conclusions }\end{array}$ \\
\hline 1/1D4 & $\begin{array}{l}\text { Pic* (basal MS) } \\
\text { Pic }\end{array}$ & - & $\begin{array}{l}0.5 /- \\
0.3 /-\end{array}$ & $2.11 \mathrm{ab}$ & $1.97 \mathrm{~cd}$ & $\begin{array}{l}\text { quick browning; FT**** } \\
\text { basal MS not convinient }\end{array}$ \\
\hline 1/2D5 & $\begin{array}{l}\text { Pic } \\
\text { Pic }\end{array}$ & $\begin{array}{l}- \\
-\end{array}$ & $\begin{array}{l}0.5 /- \\
0.3 /-\end{array}$ & $2.81 \mathrm{c}$ & $1.71 \mathrm{bc}$ & $\begin{array}{l}\text { FT; buttery, viteous callus with tendency } \\
\text { to browning }\end{array}$ \\
\hline 1/4D11 & $\begin{array}{l}\text { Pic } \\
\text { Pic }\end{array}$ & $\begin{array}{l}- \\
-\end{array}$ & $\begin{array}{l}0.2 /- \\
0.2 /-\end{array}$ & $1.90 \mathrm{a}$ & $1.48 \mathrm{a}$ & FT; auxin too low in CIM \\
\hline 2/3D10 & $\begin{array}{l}\text { 2.4-D+IBA } \\
\text { Pic }\end{array}$ & $\begin{array}{c}11+1 /- \\
-\end{array}$ & $\begin{array}{l}1.1+0.1 /- \\
0.2 /-\end{array}$ & $2.57 \mathrm{c}$ & $2.01 \mathrm{~cd}$ & $\begin{array}{l}\text { nodular tissue } \\
\text { xylogenesis }\end{array}$ \\
\hline 2/5D12 & $\begin{array}{l}2.4-\mathrm{D}+\mathrm{IBA} \\
2.4-\mathrm{D}+\mathrm{IBA}\end{array}$ & $\begin{array}{l}11: 1 /- \\
11: 1 /-\end{array}$ & $\begin{array}{l}1.1+0.1 /- \\
1.1+0.1 /-\end{array}$ & $1.86 \mathrm{a}$ & $1.67 \mathrm{ab}$ & uniform increase in weight; xylogenesis \\
\hline 3/6D9 & $\begin{array}{l}2.4-\mathrm{D} / \mathrm{BA} \\
2.4-\mathrm{D} / \mathrm{BA}\end{array}$ & $\begin{array}{l}20: 1 \\
10: 1\end{array}$ & $\begin{array}{l}2.0 / 0.1 \\
1.0 / 0.1\end{array}$ & $3.43 \mathrm{~d}$ & $2.95 \mathrm{e}$ & compact nodular tissue \\
\hline 4/7D6 & $\begin{array}{l}\mathrm{Dic} * * / \mathrm{BA} \\
\mathrm{Dic} / \mathrm{BA}\end{array}$ & $\begin{array}{l}7: 1 \\
7: 1\end{array}$ & $\begin{array}{c}1.66 / 0.225 \\
0.7 / 0.1\end{array}$ & $2.51 \mathrm{c}$ & $1.64 \mathrm{ab}$ & FT; satisfactory variant \\
\hline $4 / 8 \mathrm{D} 7$ & $\begin{array}{l}\text { Dic/BA } \\
\mathrm{Dic} / \mathrm{BA}\end{array}$ & $\begin{array}{l}10: 1 \\
6.6: 1\end{array}$ & $\begin{array}{c}2.21 / 0225 \\
1.5 / 0.225\end{array}$ & $2.48 \mathrm{bc}$ & $1.57 \mathrm{ab}$ & FT; diversified objects \\
\hline 4/9D8 & $\begin{array}{l}\mathrm{Dic} / \mathrm{BA} \\
\mathrm{Dic} / \mathrm{BA}\end{array}$ & $\begin{array}{l}6.6: 1 \\
6.6: 1\end{array}$ & $\begin{array}{l}1.5 / 0.225 \\
1.5 / 0.225\end{array}$ & $2.60 \mathrm{c}$ & 2.14 & FT; more uniform; satisfactory variant \\
\hline
\end{tabular}

*Picloram; **Dicamba; *** Friable tissue (A: auxin; C: cytokinin)

Values within column followed by the same letter are not significantly different at $\mathrm{P}=0.05$

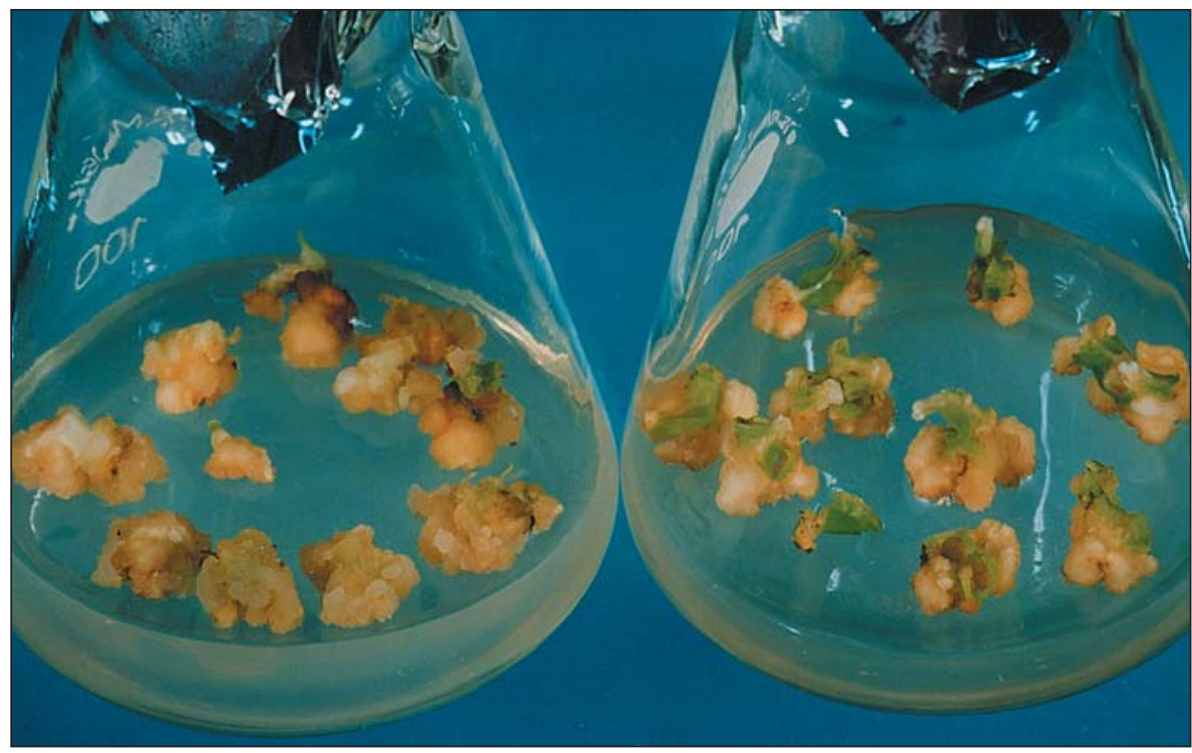

Fig. 3. Morphology of nodular, proliferative tissue cultured on modified MS medium supplemented with $2.0 \mathrm{mg} / \mathrm{l}$ of $2.4-\mathrm{D}$ combined with $0.1 \mathrm{mg} / \mathrm{l} \mathrm{BA}$. even in the case of simple multicellular fragment of lamina mesophyl, relatively homogenous with respect to cell type, initiation and maintenance of culture is still acomplished experimentally by varying conditions until the desired response is obtained. Plant growth regulators are among critical factors essential to alter the cell determinated state and initiate cell divisions in differentiated fragment of tissue. Of these, auxin is an essential supplement for the succesful culture of tissues (Gaspar et al. 2003; Huntley and Murray 1999). Varied response of explanted leaves lamina tissue in presented experiments could be explained by the fact that the initiation of proliferating cultures from population of quiescent cells involves extremely profound changes in their developmental state and simultaneously the conditions employed to induce callus exert a lasting effect even on established culture (Linsmaier-Bednar 1999; Yeoman and Forche 1981). The choice of auxin proved to be particularly important, even though auxin alone brought relatively small proportion of the cell population into division which is consistent with the results obtained by Matsua and Yamaki (1988)

In reported experiments explants formed higly proliferative, fast growing friable callus tissues when a particular level of exogenous synthetic auxin, which was always an 
absolute requirement, was combined with oxygenated cytokinin, and the account is given of the establisment of cultivation protocol for M-VI-1 Sweet Common Prune clone. Out of four auxins tested for efectiveness in establishing, such culture 2.4-D and dicamba was found to be most effective, and the effect was more pronounced in the presence of 0.1-0.2 mg/l BA in the medium, when the level of respective auxin was about $1.0-2.0 \mathrm{mg} / \mathrm{l}$. Conditions leading to the friable type of callus growth in the genus Prunus recorded by others authors are not very frequent. Sustained proliferation and the maintenance of proliferating cells in the form of friable tissue of Prunus persica was accomplished by Declerc and Korban (1996) by the use in MS medium the addition of dicamba and 2.4-D at the adequate level. Schiavone and Wisniewski (1990) adviced the same medium, but in that case 2.4-D was combined with BA, and they precised the PGR ratio as 10:1 (A:C), so this is suprisingly close to the presented results. Chen and Jouard (1994) for Prunus armeniaca pointed as best variant the medium with rather high ammount of 2.4-D with kinetine, still auxin combinated with cytokinin is also adviced here.

The chemical and physical environment provided for the cultures during the course of continued subculture of the callus select cell types, eliminating certain cell populations and perpetuating others, so even on defined medium variation between essentially similar explants is appeciable even when the explants are derived from the same mother plant. In this manner by nutritional selection of cells by the use of growth regulators callus lines can be obtained, but this problem will be undertaken in a separate paper.

\section{LITERATURE CITED}

CHEN C.S., JONARD R. 1994. Acquisition of friable calli from stems and establishment of the cell suspension cultures of Prunus armeniaca L. cv. Canino and Luizet. J. Plant Res. Environ. 3/3: 22-26.

COMPTON, M.E. 1994. Statistical methods suitable for the analysis of plant tissue culture data. Plant Cell, Tiss. Organ Cult. 37: $217-242$.

DECLERC V., KORBAN S.S. 1996. Influence of growth regulators and carbon sources on callus induction, growth and morphogenesis from leaf tissues of peach (Prunus persica L. Batsch). J. Hort. Sci. 71/1: 49-55.

GASPAR T., KEVERS C., FAIVRE-RAMPANT O., CREVECOEUR M, PENEL C., GREPPIN H., DOMMES J. 2003.
Changing concepts in plant hormone action. In vitro Cell. Dev. Biol. Plant 39: 85-106.

HANUS-FAJERSKA E., NOWAK B. 2001. The initiation, growth rate and characteristics of Prunus domesitca L. 'Węgierka Zwykła' callus cultures. Folia Hort. 2001: 481-486.

HARTMANN W. 1998. Breeding of plums and prunes resistant to plum pox virus. Acta Virol. 42/4: 230-232.

HUNTLEY R.P., MURRAY J.A.H. 1999. The plant cell cycle. Curr. Opin. Plant Biol. 2/6: 440-446.

JONES O.P. 1991. The role of biotechnology in the multiplication and improvement of woody plants. Acta Hort. 289: 35-43.

LINSMAIER-BEDNAR E.M. 1999. Historical development and current status of plant cell and tissue culture. In vitro Cell. Dev. Biol. Plant 35/2: 161-162.

MALEPSZY S. (ed). 2001. Biotechnologia roślin. PWN, Warszawa.

NOWAK B., MICZYŃSKI K. 1996. Regeneration capacity of Prunus domestica L. cv. Węgierka Zwykła from leaf explants of in vitro shoots using TDZ. Folia Horticulturae 8/2: 41-49.

NOWAK B., MICZYŃSKI K. 2002. The course and efficiency of organogenesis on leaf explants of plum 'Węgierka Zwykła' (Prunus domestica L.) induced by cytokinins. Electronic J. Pol. Agricult. Univ. Vol. 5/1, ser. Biotechnol., art - 0.2.html

NOWAK B., MICZYŃSKI K. HUDY L. 2004. Sugar uptake and utilisation during adventitious bud differentiation on in vitro leaf explants of 'Węgierka zwykła' plum (Prunus domestica). Plant Cell, Tiss. Organ Cult. 76: 255-260.

MATSUTA N., YAMAKI S. 1988. Callus induction from leaf disks of stone fruits (Prunus spp). Bull. Fruit Tree Res. Stn., Tsukuba, Ibaraki, Japan, Ser A. 15: 19-30.

NAVRATIL M., SAFAROVA D., KARESOVA R., KUCEROVA J., PAPRSTEIN F. 2005. Experimental screening of plum genotypes for resistance to plum pox virus (PPV). Phytopathol. Polon. 36: 67-70.

PEREZ-FRANCES J.F., VALDES F., MARTIN R. 1995, Callus induction and culture from explants of Erysimum scoparium in a growth-regulator free medium. Plant Cell, Tiss. Organ Cult. 43: 223-228.

PREDIERI S. 2001. Mutation induction and tissue culture in improving fruits. Plant Cell, Tiss. Organ Cult. 64: 185-210.

SASAKI T. 2004. Plant biotechnology. Curr. Opin. Biotechnol. 15: 117-119.

SCHIAVONE F.M., WISNIEWSKI M.E. 1990. Callus and cell suspension cultures from dormant stems of peach. Hort. Sci. 25/4: 483 .

STEC W.J. 1994. Dlaczego należy przyjmować nowoczesne biotechnologie? Post. Biol. Kom. 21/2: 105-120. (in Polish)

YEOMAN M.M., FORCHE E. 1981. Cell proliferation and growth in callus cultures. Int. Rev. Cytol. Suppl. 11A: 2-24. 